\title{
Russian Science Prior to the Russian Revolution
}

\author{
Agamenon R. E. Oliveira \\ Polytechnic School of Rio de Janeiro, Federal University of Rio de Janeiro, Rio de Janeiro, Brazil \\ Email: agamenon.oliveira@globo.com
}

How to cite this paper: Oliveira, A. R. E. (2018). Russian Science Prior to the Russian Revolution. Advances in Historical Studies, 7, 113-134.

https://doi.org/10.4236/ahs.2018.73008

Received: March 21, 2018

Accepted: August 7, 2018

Published: August 10, 2018

Copyright $\odot 2018$ by author and Scientific Research Publishing Inc. This work is licensed under the Creative Commons Attribution International License (CC BY 4.0).

http://creativecommons.org/licenses/by/4.0/ (c) (i) Open Access

\begin{abstract}
This paper is an attempt to present and discuss the scientific context prior to the outbreak of the Russian Revolution in 1917. Some general aspects of the scientific milieus of the eighteenth and nineteenth centuries are described, including the period of Peter the Great, the foundation of the Academy of Science, and the influence of great figures of science, both Russian and foreign. In the eighteenth century, Euler (1707-1783) and Lomonosov (1711-1765) were chosen as symbolic and representative figures, while in the nineteenth century, Lobachevski (1792-1856), Chebyshev (1821-1894), Mendeleev (1834-1907), and Pavlov (1849-1936) were looked.
\end{abstract}

\section{Keywords}

History of Russian Science, History of Russian Revolution, Great Figures of Science, History of Russian Education

\section{Introduction}

The Russian revolution in 1917 was one of the most radical turning points in Russia history. It affected economics, social structure, culture, international relations, and industrial development, amongst other transformations. The revolution opened the door for Russia to enter the industrial age and consequently to achieve modernity (Carr, 1979).

Before 1917, Russia was an agrarian nation, with only very limited industrial development. However, the pre-1917 scientific base was of fundamental importance for propelling the country forward and for technological advances, such as electrification and new urban-industrial regions which appeared almost immediately (Kirchner, 1982). Education also played a major role, with illiteracy being practically eradicated.

Using the scientific background from the pre-revolutionary period, during the 1920s, the Soviet state changed research organizations into an institute system 
1920s (Graham, 1993). From the revolutionary viewpoint, the term scientific-research institute (nauchno-issledovatel'skii institute) had another meaning and structure. Almost all outstanding scientists and engineers were members of, or had a commitment to, an institute. Another very impressive characteristic of the history of Russian science, mainly in the nineteenth century, is the role and the participation of women (Koblitz, 2013). In fact, Russia had the highest contribution of women to scientific activities in the world, looked in terms of doctorates in mathematics, physiology, zoology, chemistry, and in many other fields.

\section{Russian Science in the Eighteenth Century}

The two major traditions in Russian science in the above period were mathematics and studies of natural resources. Furthermore, these traditions have continued until the present. In both, but especially in mathematics, foreign researchers dominated, notwithstanding many works written by Russians at the end of the eighteenth century. The most famous case is Leonhard Euler who came to St. Petersburg to study mathematics and physics (Oliveira, 2007). He arrived in 1727 as an assistant professor of physiology. Other examples of foreign academics include Daniel and Nicolaus Bernoulli.

The contributions of Euler and the Bernoulli brothers alone gave St. Petersburg prestige and honor in the history of mathematics. They came from Basil. Euler spent two long periods in St. Petersburg, from 1727 to 1741 and from 1766 until his death in 1783. The majority of his works was written in St. Petersburg. Euler arrived young in Russia, twenty years old and received his professional education there. With respect to the Bernoullis, Nicolau's career was interrupted by his death with the age of thirty-one. Daniel stayed only seven or eight years in St. Petersburg, before returning to Basil, but in Russia he started writing his famous book Hydrodynamics (1738) which contains the Bernoulli principle (Bernoulli, 1738).

Critics of Russian science in the eighteenth century have argued that these contributions are much better described as Russian carried out by European scientists, and some of whom actually returned to their original countries. Another comment that appears is that the high-level mathematics studies encouraged were far from the educational necessities of the country and were at the very least a distortion of priorities. However, these studies consolidated the Russian mathematical tradition (Karp \& Vogeli, 2010). Even if we look at Euler's work, obviously he did not work alone in St. Petersburg, where he created a school for young people that have continued his work after his death. Some of his disciples include Stepan Rumovskii and S. K. Kotel'nikov who significantly help Russia enter the field of contemporary mathematics, where it still has a leading place.

The second great scientific heritage in the eighteenth century was studies of natural resources, often obtained through expeditions. The American historian 
of Russian science Alexander Vucinich has found 161 published studies that came from these expeditions in Russia in the period 1742-1822 (Graham, 1993). The eminent German naturalist Peter Simon Pallas (1741-1811) became a member of the St. Petersburg Academy and spent almost his entire adult life in Russia, from the age of 26 until 69.

Mathematics and natural history in the eighteenth century were the areas where Russian science acquired its most remarkable position from the viewpoint of its contribution to European science (James, 2002). In addition, the St. Petersburg Academy was responsible for the translation of many European scientific works and helped the government solve many technical questions, as well as contributing to the promotion of scientific education in the country.

Moscow University, founded in 1755, made few contributions to science in this period despite providing the organizational foundations for the development of science in the next century (Brooke, 2006).

Finally, since the beginning of the eighteenth-century Peter the Great had tried to bring European science and technology to Russia having a remarkable role to do this regarding the top of the Academy. His critics did not always agree with his methods, but he always replied saying that his successors would continue and complete his project.

\subsection{Science in the Peter the Great Period}

Peter the Great (Figure 1), the 'Reformer Tsar Reformer,' whom the Russians generally call Peter I (Pyotr Pervy) was born in Moscow, on June 9, 1672. He died in St. Petersburg, on February 8, 1725 and is entombed in Cathedral of Saints Peter and Paul, located in St. Petersburg (Anderson, 1978).

The reign of Peter the Great (1689-1725) has a special importance in Russian history, mainly due to the introduction of Western European science in the country. It is possible to argue that many of these reforms were suggested by his father Alexis. Moreover, Moscow had previously received foreign influences and culture from other European countries which had left their marks. Nevertheless,

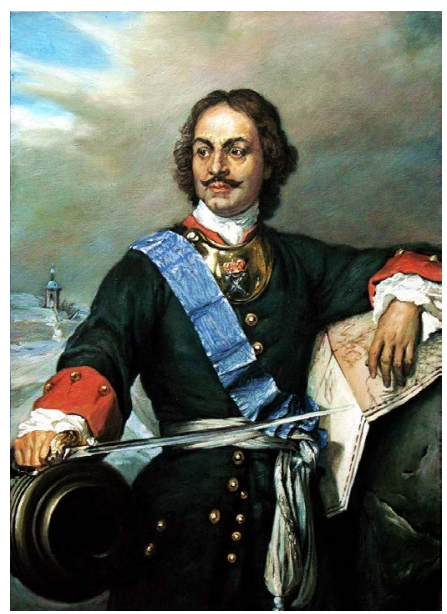

Figure 1. Peter the great (Portrait by P. Delaroche). 
in spite of these previous influences, it is generally accepted that the process of disseminating European culture in Russia began with Peter the Great.

At the end of the eighteenth-century Russia did not have scientific organizations, although religious institutions existed in Kiev and Moscow for teaching languages and religion.

The first prominent Russian scientist was Mikhail Lomonosov (1711-1765), educated in these institutions. In 1701, Peter the Great created a navigation school in Moscow and a naval academy in 1715, in St. Petersburg. In addition, an artillery school, an engineering school, and a medicine school were also founded during his reign.

Peter thus created a favorable atmosphere for the penetration of European science and culture in Russia, in contrast with his predecessors (Owen, 1995). Hence, in his reign a small part of the Russian population, mainly belonging to the nobility but also including some academics and literati, began to see West European culture as something desirable.

Despite his poor education, Peter the Great understood that for Russia to become competitive in the context of European politics more had to be done than just importing specialists and copying the models of other European armies. To achieve this, he visited science academies in France, England, and Prussia, the Greenwich observatory, as well as other places in Europe where scientific research was being carried out. He decided that Russia should create this type of institution.

\subsection{The Foundation of the Academy of Science}

In contrast with other European countries Russia did not have any universities at the time of the foundation of the science academy. This increased the prestige of the academy for a long period. At the end of nineteenth century Russian universities overtook the Academy of Science, a trend that led to the decline of prestige and research effort in this institution, making it more of an honorific place (Graham \& Dezhine, 2008). This transition was not complete when Russian Revolution radically changed the political context in 1917. The Soviet government adopted a policy of increasing the prestige of academies after 1917, something which reminds us of the Peter the Great period.

Peter the Great, inspired and advised by Leibniz (1646-1716), founded the Academy of Science in St. Petersburg by means of the Senate decree of February 8, 1724. Originally called The Saint Petersburg Academy of Science, it changed name various times during the years. In 1836 it was named the Imperial Saint Petersburg Academy of Science (Figure 2) which lasted until the end of the empire in 1917.

When Peter decided to create a scientific society, there were several models from other European academies to choose from, many of which he knew personally. He maintained fruitful correspondence with Leibniz, founder and president of the Berlin Academy. He also exchanged opinions and experiences with 


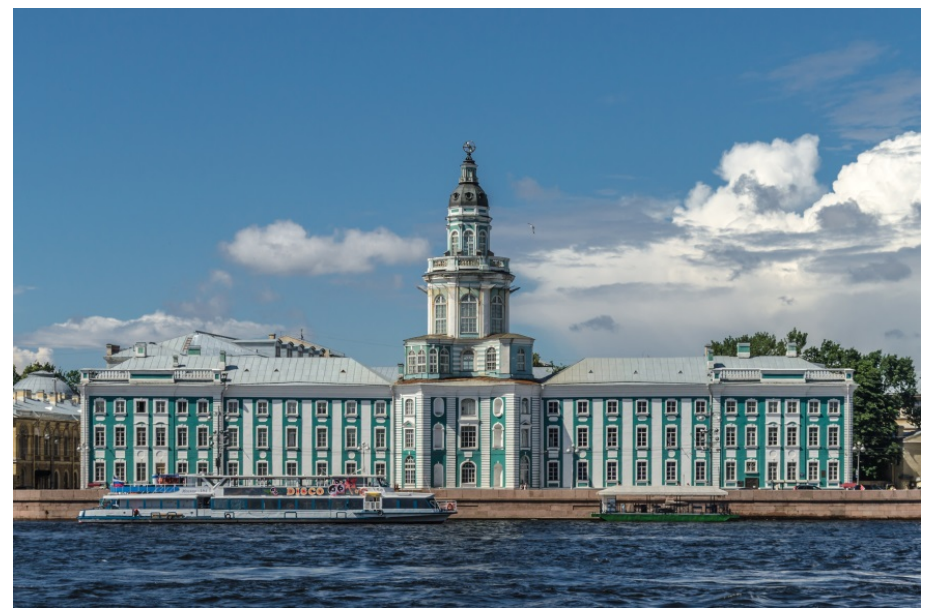

Figure 2. Original building of the imperial academy of science.

Christian Wolff, professor at Halle University and later in Marburg. He was helped by Lavrentii Blumentrost (1692-1755), the court physician charged with designing a final plan for this organization. Blumentrost's model was approved by Peter the Great before his death, adopting many details of foreign academies.

One goal of this new orientation was to cultivate native Russian science (Lieven, 2006). Its structure permitted the presence of foreign academics at the top, offering the possibility of scientific investigations at the highest level and providing professors in special scientific fields. The foreign professors would bring students from other universities to interact with Russian students, while the university's students would act as (assistant) professors in a kind of third level of the Academy, under the condition of teaching at the gymnasium school and being Russian citizens. In other words, the objective of the development of Russian science was to gradually increase the Russian elements.

Over time some important elements of the original project were changed. The Academy became in part a foreign institution and many members were German speakers. The first Russian member was not elected until twenty years after its foundation. Only after a century and a half did ethnic Russians win control of the Academy.

From the administrative viewpoint, the Academy was treated as a branch of government and naturally submitted to imperial command. The original project drafted by Blumentrost and approved by Peter allowed for self-government including the right to elect their own members and the president. However, this was obtained late, because the right to elect the president was hidden from the members. This right was maintained until the provisional government in 1917.

In spite of initial difficulties, the Academy became a competent institution. Among the foreign members who came to St. Petersburg it is possible to find famous scientists who helped Russia to become familiar with European science.

\subsection{Great Scientists in the Eighteenth Century}

Leonhard Euler (1707-1783) 
Leonhard Euler (Dictionary, 2007) is undoubtedly the most important mathematician of the eighteenth century (Figure 3). He was born in the vicinity of Basil, in northern Switzerland near the French border, on April 15, 1707, the son of Paul Euler and Margaret Bruchner. After first being taught by his father, Euler went to university at the age of thirteen, where he demonstrated a rare aptitude for mathematics. In addition, he studied with Jean Bernoulli and was directly influenced by Leibniz (1646-1716) and Descartes (1596-1650), mainly in mathematics and philosophy. He received mechanical theory from Newton (1642-1727).

He adopted and used Leibniz's mathematical theory for finite and infinitesimal quantities, as well as adopting Newton's concept of force, but diverged with the latter in relation to the idea of absolute space.

At seventeen he wrote a paper on the 'Physical demonstration of sound.' This is Euler's first noteworthy work and had a significant influence on research into acoustics.

When Euler was twenty-one he was nominated by Daniel Bernoulli to the St. Petersburg Academy of Science. In 1733 he succeeded him as mathematician in that Academy. Here he improved integral calculus, developed the theory of trigonometric and logarithm functions, and worked hard to simplify analytical expressions in mathematics.

Probably because of his intense intellectual effort, Euler became partially blind in 1735. In 1741 Frederick the Great invited him to the Berlin Academy. He left Russia and stayed in Berlin for 25 years. During this period Euler produced a significant amount of scientific work. In 1748 in "Introductio in analysin infinitorum," he developed the concept of function as we now know it. In 1755 he wrote Differential Calculus (2 Vols.), afterwards writing Integral Calculus (3 Vols.) which was published in St. Petersburg (1768-1770). All these books guided mathematicians for many years, and it can be said that all eminent mathematicians living towards the end of the eighteen century and at the beginning of the nineteenth were Euler's pupils.

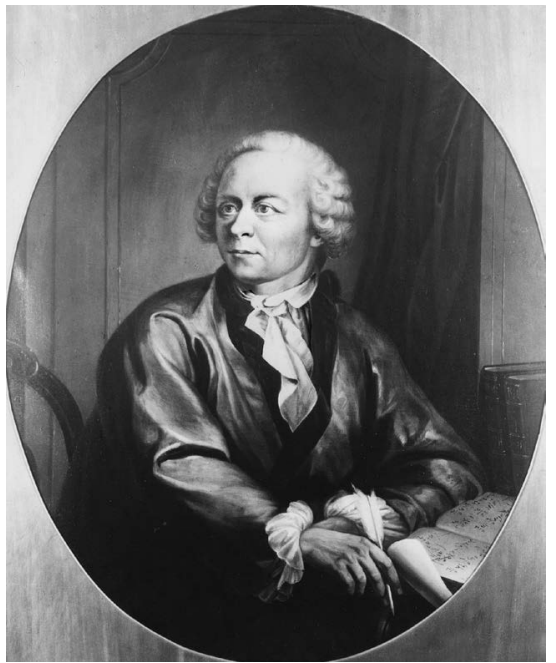

Figure 3. Leonhard euler (1707-1783). 
In 1776 he returned to St. Petersburg to the court of Catherine II (1729-1796). Euler was now practically blind. In spite of this his extraordinary memory helped him to maintain the same considerable rate of work. He was also aided by assistants in order to organize his papers and manuscripts. However, this did not stop his activity, and the number of papers he wrote in this period was greater than ever. To accomplish this task, Euler gave complete explanations of new problems to the assistants. With this information, his assistants were able to go ahead with his new papers, though Euler obviously analyzed the results before giving final approval. More than 400 papers were produced by him during this last period (1766-1783). More than forty years after his death the Russian Academy of Science was still publishing his papers in its annual memoirs.

Euler married Katherine Csell in 1753 and had thirteen children, of whom only eight survived. One of these, Johann Albrecht (1734-1800), reviewed and continued his father's work on rigid bodies. A descendant of Euler, Hans Karl August von Euler-Chelpin (1873-1964), received the Nobel Prize for Chemistry in 1929.

Euler's achievements in mathematics are well known. He studied elementary geometry, trigonometric functions, discovered the imaginary logarithms of negative numbers, showed that each complex number has an infinite number of logarithms. He demonstrated the identity $\mathrm{e}^{i \theta}=\cos \theta+i \operatorname{sen} \theta$, in which when carrying out $\theta=\pi$ one discovers the relation $\mathrm{e}^{i \pi}+1=0$. As we can see the most famous numbers appear.

Euler introduced the modern nomenclature we know today to mathematics, namely the symbols, $\Sigma$ for any summation, e the Neperian logarithm base, $f(x)$ representing a function of the independent variable $x$ and $i$ to represent the complex number $\sqrt{-1}$. He was the first to use the derivative of a function as a limit of the ratio between two variable quantities.

Euler died on September 18, 1783. He left on his desk some manuscripts and calculations on the problem of aerostatic balloons. This was his last scientific concern.

Mikhail Vasilievich Lomonosov(1711-1765)

Lomonosov (Pavlova et al., 1984) was the first eminent Russian scientist who worked in various fields, such as chemistry, physics, mineralogy, mining, metallurgy and optics (Figure 4). In addition, he was interested in history and dedicated some time to poetry.

Lomonosov was born in a small village of Mishaninskaia, in the extreme north of European Russia on the White Sea. It seems almost improbable that there would appear from this remote place a scientific figure capable of developing leadership in Russia science in relation to the European context.

In 1730, Lomoosov received permission from local authorities to go to Moscow in order to try to enter the Slavic-Greek-Latin Academy, the best Russian educational institution at that time. It was an Orthodox institution, and had deep roots in Russian intellectual traditions, both Greek and Catholic, as well the Latin one that came from Kiev. However, Lomonosov faced a serious problem, 


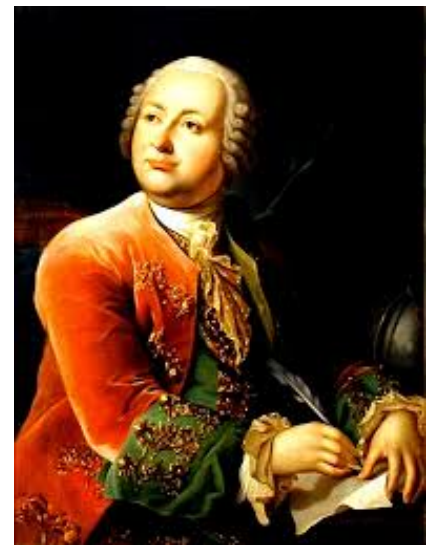

Figure 4. Mikhail Lomonosov (1711-1765).

peasants could not be admitted to the Academy. He was obliged to deny his origin and presented himself as the son of a priest.

Fortunately, at that moment in Russia a kind of Westernization occurred and in 1735 the Academy of Science gained increasing prestige, though the majority of its members were from abroad. Moreover, it required from monasteries and ecclesiastic academies university students to study with foreign academicians. Lomonosov was sent with eleven students to the St. Petersburg Academy where he began to study mathematics and physics.

Some other events were favorable to Lomonosov's career. The academy was organizing expeditions for explorations in Siberia and in the arctic region and required a chemist with experience in mining for seeking valuable minerals. With the lack of this type of professional in St. Petersburg, the Academy decided to technically prepare someone to fulfill this need by sending them to study in the Universities of Marburg and Freiburg. Lomonosov was thus sent to Western Europe in 1736 where he stayed for almost five years. He studied in Marburg with Christian Wolff and in Freiburg with Friedrich Henkel.

After returning to St. Petersburg, Lomonosov became assistant professor in the Academy of Science in physics and later professor of chemistry. In 1748 he opened the first chemical laboratory in Russia, similarly equipped to the European labs. Later he also became head of the geography department of the Academy.

Lomonosov's scientific activities can be divided in three periods: from 1740 to 1748 when he basically worked on theoretical physics. In this period, he wrote and taught on matter corpuscular theory, heat theory, and air properties. As result of these investigations in $\mathbf{1 7 4 6}$ he published the first physics' work in Russian. However, the majority of his publications were in Latin. From 1748 to 1757, after the construction of his chemistry laboratory, he hardly worked in this discipline, studying chemical affinity, the production of glass and mosaics, the freezing of liquids, and the nature of substance mixtures. From 1757 until his death in 1756, Lomonosov was involved in scientific administration, mining and metallurgy as well as navigation problems. During all of these periods he con- 
tinued to write poetry and to promote the language and Russian history.

With respect to influences on him, it is worth emphasizing corpuscular matter theory, in vogue during the seventeenth century and at the beginning of the eighteenth, influenced by the ideas of Pierre Gassendi, Descartes, and Boyle. However, also important was the influence of Christian Wolff, his professor in Marburg. Leibniz's thought, mainly his theory of knowledge and his Monadology, also influenced him.

Finally, Lomonosov had a particular way of describing nature through figures and mechanical models, leading to the establishments of fruitful connections and useful consequences.

\section{Russian Science in the Nineteenth Century}

During the nineteenth century Russian science developed enormously. All education levels were rising, from elementary to the universities, as well as the highest level of scientific research. However primary education continued to be a problem until the following century.

In the nineteenth century Russia had a great number of figures and a certain level of scientific leadership, even in the international context, including Nikolai Lobachevski, F. G. W. von Struve, Dimitri Mendeleev, Pafnustii Chebyshev, Illia Mechnikov and Ivan Pavlov, amongst others.

At the end of the nineteenth century Russia as a nation continued to be in a backward position from an economic and political perspective (Chakravanti et al., 1987). Looked at from a scientific point of view, however, significant progress with respect the previous century cannot be denied. In 1900, compared with Germany, France, and Great Britain, Russia was behind them, but the distance had been enormously reduced. However, this century involved long periods of academic reaction and intellectual retrogression as result of political reforms implemented by the autocracy, as well as western ideological influences.

At the beginning of the reigns of Alexander I (1801-1825) and Alexander II (1855-1881), the most innovative periods, great advances were made which were partially reversed in subsequent periods of reaction. Nevertheless, even in these periods many advances continued to be made in science and technology education.

Alexander I and his staff decided that the first step to definitively solve educational problems in Russia was the creation of an education ministry. In 1802 this was created and lasted until the Russian Revolution in 1917, which was charged with the administration of a very impressive system of schools in four levels: elementary or parish schools, district schools, provincial schools, and universities.

The Russian empire had only one city with university, Moscow, when Alexander acceded to the throne, but he added more three universities: in Kazan, Khar'kov (1804), and St. Petersburg (1819). With the help of the Academy of Science, the system worked as a lever to move forward the development of 
science and scientific education in Russia. This model, to some extent was inspired by the Polish system, but it went beyond this because of its classical education elements. Higher education in Poland started in the Middle Ages. In 1364, was created the first Polish University in Cracow. In 1826, the first technical university was established in Warsaw. In addition, Poland was the first country in the world to create a ministry of education.

It is also necessary to emphasize that the public dimension introduced in Russia was inherited from the French Revolution. In 1792 Condorcet introduced through the National Convention the commitment that each child should be giving an opportunity to develop until the limit of their innate potential. At the beginning of Alexander's reign, the tsar and his staff adopted this characteristic of Condorcet's plan. All educational levels in Russia were thus in principle open to all social classes, including both sexes. In addition, there are no tuition fees, while the state also supported the studies of poor people.

Despite the written rules, this system did not work. No woman went to university during Alexander's reign. Social pressure was much stronger than official rules.

In the second part of Alexander's reign the cost of the Napoleonic wars became too heavy for his government to support the educational system. At the same time the tsar became more conservative and mystic. French Revolution ideas were left aside and nationalist thought became dominant.

Nicolaus I (1825-1855) was a conservative and militarist tsar who imposed his ideas on Russian intellectual life using strong bureaucratic control. Paradoxically, in this period there flourished original literature, including writers such as Pushkin, Lermontov, Gogol, Dostoievskii, Nekrasov and Turguenev. In the sciences a similar wave of eminent scholars appeared: Lobachevskii in mathematics, Struve in astronomy, von Baer in zoology, Hess in chemistry, Lenz in physics and many others. Yet in Nicolaus' reign the reforms of Count S. S. Uvarov introduced many changes to the educational Russian system. He promoted a renaissance in the Academy of Science with the introduction of a new system of scholarships in universities. In addition, he created a tradition of excellence to evaluate student performance and strongly supported mathematical studies.

A second great period of reforms in Russian science came with the Crimea War during the reign of Alexander II (1855-1881). This war highlighted Russian technological weakness, which had been much behind Western European states since the Napoleonic period, when Russia demonstrated its power to Europe. The government concluded that with social and economic system modernization of Russia was impossible. However, educational reforms had a greater impact on the scientific system. University admissions increased significantly, but the privileges of social class implied a decrease in student participation in the applied sciences. Foreign travel for studying was again permitted, while the education of women up to the secondary level was stimulated. New rules for universities established in 1863 eliminated the majority of restrictions created by rules intro- 
duced in 1835 .

Some reformers proposed that women should be admitted into universities, but this suggestion was not accepted. Instead of this, a few years later special higher-level courses were created for women, in special faculties separate from universities. In the 1860s and 1870s a remarkable generation of Russian women looked for more advanced educations in those courses or in Western Europe. This encouraged women to receive doctorates in several scientific fields. The mathematician Sofia Kovalevskaia (1850-1891) became a leader in the field of partial differential equations. She was the first famous Russian mathematician and one of the most important since antiquity.

\section{Great Scientists in Nineteenth Century}

\section{Nikolai Ivanovich Lobachevsky(1792-1856)}

Lobachevsky (Dictionary, 2007) was born in Nizhni Novgorod, now Gorki, on December 2, 1792 and died in Kazan in February 24, 1856 (Figure 5). His parents were Ivan Maksimovich Lobachevsky and Praskovia Aleksandrovna Lobachevskaya. Around 1800, his mother moved with three children to Kazan. In 1807, Lobachevsky entered Kazan University studying with Martin Bastels, a friend of Gauss, obtaining in 1812 the MSc title in mathematics and physics. In 1824 he became assistant lecturer in mathematical and physical sciences, starting to teach mathematics and mechanics. The example follows.

At this time, he was appointed an extraordinary lecturer in 1814, becoming a regular lecturer in 1822, the same year he started an administrative career having been made responsible for monitoring the construction of many university buildings.

Due to his fruitful work, in 1837 Lobachevsky was granted a hereditary noble title. He also married Lady Varvara Alcksivna Moisieva in 1832, but due to family problems he retired from university. At this time, he fell ill, suffering from a degenerative disease that appears to have affected his vision. He became blind in his final years.

Lobachevsky's first important work, Geometriya, was written in 1823, though

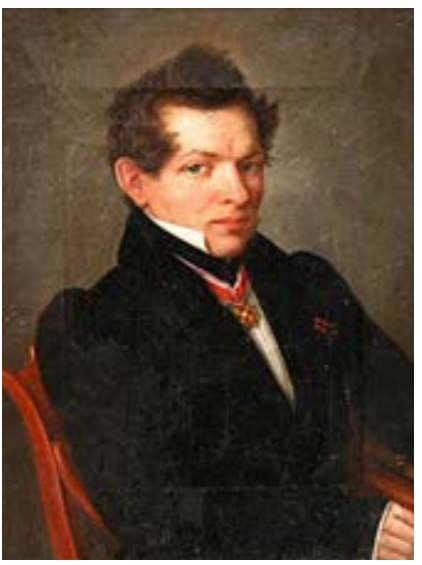

Figure 5. Nikolai Lobachevsky (1792-1856). 
it was only published in its original form in 1909. These studies led him to his most important discovery, non-Euclidean geometry, also known as hyperbolic geometry and explained for the first time in: Exposition succinte des principes de la geometrie avec une demonstration rigoureuse du théorème des paralleles. This paper was presented to the Kazan Department of Physics and Mathematics in a meeting held on February 23, 1826.

Lobachevsky's non-Euclidian geometry is a result of two thousand years of criticism of Elements. Historically, mathematicians had continuously criticized Euclides' fifth postulate which stipulated:

If a line segment intersects two straight lines forming two interior angles on the same side that sum to less than two right angles, then the two lines, if extended indefinitely, meet on that side on which the angles sum to less than two right angles (see Figure 6 and Figure 7 ).

The converse of the parallel theorem is shown in Figure 7 below.

In his classes Lobachevsky tried to prove the fifth Euclidian postulate. His geometry was then derived from the conclusion that a new kind of geometry was possible, in which all Euclidian axioms, except the fifth, was still valid, and did not contain any contradictions. He called this system imaginary geometry, using an analogy with imaginary numbers. If there are much more general numbers, in which arithmetic laws of real numbers can be justified, then in his imaginary geometry, we can also expect that this one would be more general. Consequently, he rejected the unicity of Euclidean geometry, that it is a particular case of a more general system. Hence in Lobathevsky's geometry, for a given straight line

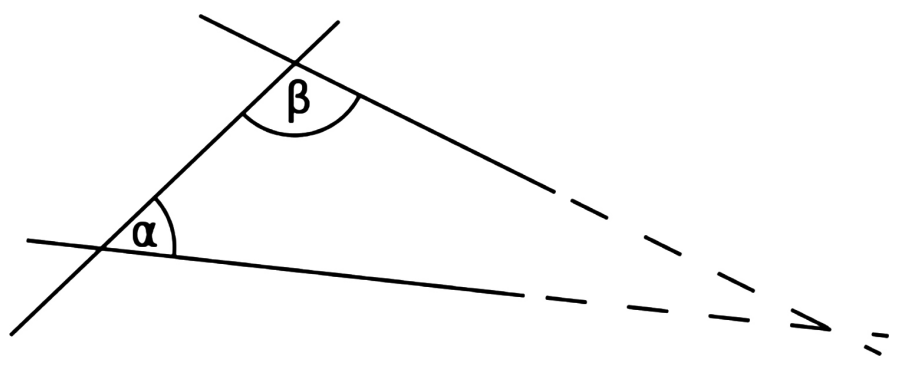

Figure 6. If the sum $\alpha+\beta$ is less than 180 , the two straight lines, meet on that side.

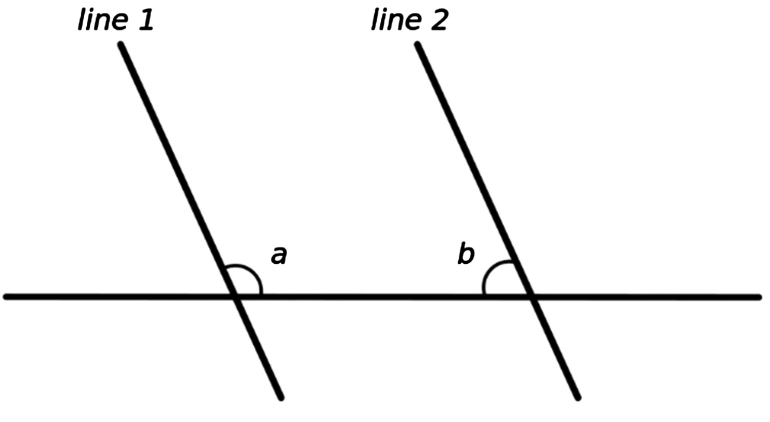

If: $\quad a+b=180^{\circ}$

Then: $\quad$ line 1 and line 2 are parallel

Figure 7. The converse parallel theorem. 
$a$ and a point $A$ not belonging to a, it is possible to trace through $A$ more than one straight coplanar straight line that does not intersect $a$.

Lobachevsky's work was not well received by mathematicians during his lifetime. Even in Russia, his contemporary, the mathematician, M. V. Ostrogradsky from the St. Petersburg Academy of Science, did not understand Lobachevsky's achievements and published a report criticizing him: On geometry's principles. Only Gauss who received Lobachevsky's book Geometrical investigations, agree with his election to the Göttingen Sciences Society.

\section{Pafnuty Lvovich Chebyshev (1821-1894)}

Chebyshev (Dictionary, 2007) was born in Okatovo, on May 16, 1821 and died in St. Petersburg in December 8, 1894 (Figure 8). He was descended from a minor noble family. His father, Lev Pavlovich Chebyshev, was a retired army officer who had fought in the war against Napoleon. Agrafena Ivanovna Pozniakova, his mother, had raised nine children; the youngest Vladimir Lvovich became a famous general and professor in the Artillery Academy of St. Petersburg.

In 1832, Chebyshev's family moved to Moscow, where he completed his secondary studies at home. He learned mathematics with P. N. Pogorelski, the author of many popular elementary mathematics books. The example follows.

In 1837, Chebyshev entered the Department of Physics and Mathematics of Moscow University. Mathematics was taught by N. D. Brashman and N. E. Zernov. The first had a great influence on Chebyshev's scientific development. In a letter addressed to the latter, Chebyshev acknowledges the importance of his guidance in the classroom as well as many dialogues and profitable discussions. This letter was read in a session of the Moscow Mathematics Society in September 30, 1865. It also appeared in the first issue of Matematichesky sbornik (Mathematical collection) published by the same society in 1866 . Chebyshev was one of the first members of the society, Professor Brashman was a founder and its first president.

While still a student, Chebyshev wrote Vychislenie korney uravneny (Calculus of roots equations) in which he proposed an iterative and original method for calculating approximately real roots of algebraic equations, $y=f(x)=0$. The

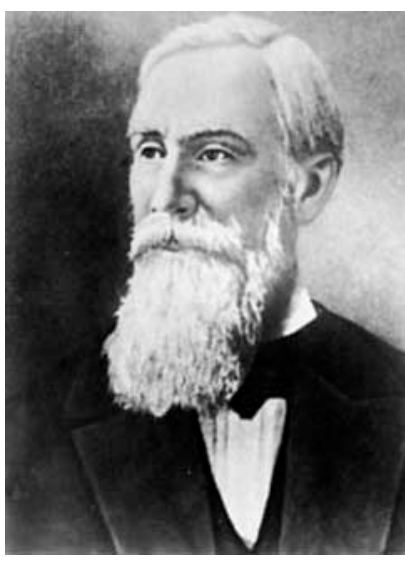

Figure 8. Pafnuty Chebyshev (1821-184). 
method was based on a series expansion of the inverse function $x=F(x)$. In terms of the numerical results obtained, comparing the first order approximations, it is equivalent to the well-known Newton-Raphson method. In addition, his method also provides for error estimation.

In the spring of 1841, Chebyshev received his degree in mathematics from Moscow University, but continued his studies under the guidance of Brashman. He began a MSc program in 1843 and at the same time published a paper on multiple integrals theory in Journal des Mathématiques Pures et Appliquées, edited by the famous French mathematician Liouville (1844). Another paper about the convergence of Taylor series appeared the Journal für die reine und angewandte Mathemati. In 1846 he presented his MSc dissertation: Opyt elementarnogo analiza teorii veroyatnostey (Essay and analysis of the elementary theory of probability).

He moved to St. Petersburg University as an assistant professor. In September, 1847, Chebyshev began to teach advanced algebra and number theory. Later, he taught other disciplines including integral calculus, elliptic functions, and finite difference calculus. At this time in St. Petersburg, Chebyshev began to work with Bunyakovski on a new edition of Euler's works about number theory. This was demanded by the Russian Academy of Science. It was published as: L. Euleri Commentationes arithmeticae collectae, 2v. (St. Petersburg, 1849). This project encompassed not only Euler's articles on number theory, but many archives and manuscripts provided by Academy.

Number theory drew the attention of Chebyshev. He entered deeply into it and developed congruence theory (Teoria stravneny) which was chosen and presented as his $\mathrm{PhD}$ thesis in mathematics at St. Petersburg University, May 27, 1849. He won a prize from the Science Academy for this work. In addition, his findings were extensively used and many books propagated his ideas for a long time in Russian universities.

In 1850, Chebyshev was elected extraordinary professor in mathematics at St. Petersburg University. In 1860, he became full professor. It is important to emphasize that during this decade he wrote his famous studies on mechanisms which implied important improvements in the theory and a better approximation of functions.

These developments in mechanisms led him to Moscow University, where he increased his interest in technological problems, especially mechanical engineering. Between 1849-1851 he taught courses on applied mechanics in the Department of Practical Knowledge, a kind of engineering department in St. Petersburg University. Among his many technological concerns, Chebyshev studied the steam engine and propeller mechanisms using articulated levers. As a consequence, he began to develop a general theory of mechanisms, arriving at some analytical problems, not previously known or even studied by his contemporary mathematicians. These problems led him to new achievements related to find a better approximation of functions. 
Chebyshev is important in the history of science not only because of his mathematical findings, but also due to the foundation of a great school of mathematics. This school is sometimes known as the Chebyshev School but is more frequently called the St. Petersburg School, because the majority of its representatives belonged to the St. Petersburg Academy of Science. Some of Chebyshev's older contemporaries, such as Bunyakovski and Ostrogradski, also taught in the mathematical school attached to the Academy. However, Chebyshev founded this school, guided it, and inspired and influenced for a long time the trends of mathematics in St. Petersburg University

For more than 50 years the professors in the school were Chebyshev's disciples. Moreover, in addition to achieving a high academic level, the school also disseminated Chebyshev's ideas to the other Russian Universities. During this period the St. Petersburg school of mathematics became one of the most important around the world and obviously the best in Russia. The following mathematicians belonged to that school: A. N. Korkin, Y. V. Sohotski, E. I. Olotavo, A. A. Markov, A. M. Lyapunov, K. A. Posse, D. A. Grave, G. E. Voroni, A. V. Vasiliev, V. A. Stelkov, and A. N. Krylov.

\section{Dmitry Ivanovich Mendeleev (1834-1907)}

Mendeleev (Dictionary, 2007) was born in Tobolski, now Tyumen Oblast, a Siberian town, on February 8, 1834 and died in St Petersburg in February 2, 1907 (Figure 9). He was the 14th and youngest child of Ivan Pavlovich Mendeleev, lecturer in Russian literature and Maria Dmitrievna Kornileva, descendant of an ancient family of merchants and owner of a glass factory near Tobolski. At seven he entered Tobolsky Gymnasium, where he graduated in 1849. For several years he lived close to the glass factory, where industrial problems drew his attention.

In 1850, Mendeleev entered the St. Petersburg Faculty of Physics and Mathematics, attached to the Principal Pedagogic Institute. He had the following teachers: A. A. Voskresensky who taught chemistry and encouraged him to perform chemical experiments; the geologist and mineralogist Kutorga who introduced him

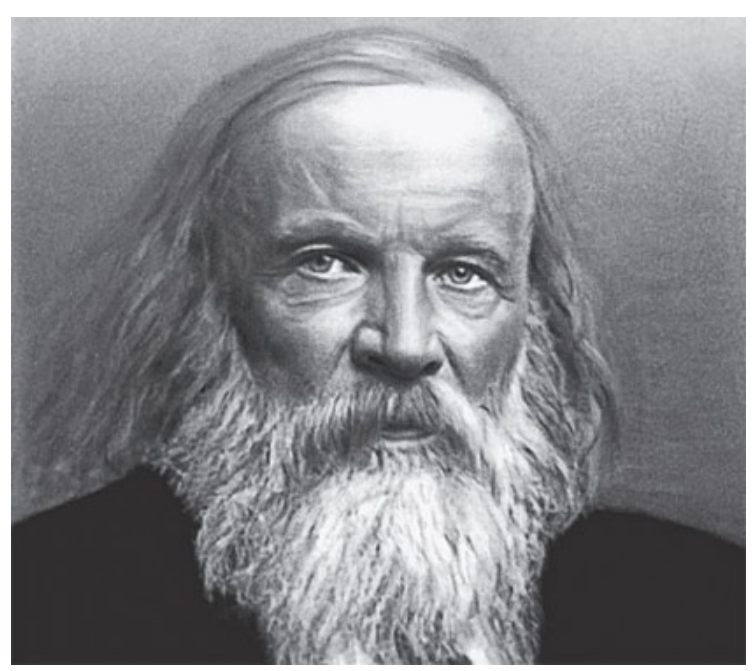

Figure 9. Dmitry Ivanovich Mendeleev (1834-1907). 
to methods of research. Mendeleev graduated from the Institute in 1855 with brilliant results. He wrote the text: Izomorfizm $v$ svyai s drugimi orno sheniami formy $k$ sostavu (Isomorphism with association with other forms related to composition), published in Gorny Zhurnal (Mining review) in 1856. This work led him to undertake a comparative study of the chemical properties of substances.

His MSc thesis was entitled Udelnye obemy (Specific volumes) as a natural consequence of previous articles in which he investigated the relationships between chemical and crystallographic properties of substances and their specific volumes. At this time, he began to incorporate many industrial concerns in his research, in which economic problems were also considered.

Mendeleev also agreed with Gerhardt's ideas which refuted Arrhenius' electrolytic theory, rejecting the concept of an ion as an electrically charged molecular fragment and not recognizing the existence of the electron.

He was, thus, completely opposed to the idea that chemical bonds were related to electricity, though he agreed with the proximity of chemistry and physics as a kind of mass science. This vision was theoretically supported by the correlation of chemical properties and weights of atomic elements. From the methodological point of view he was not a chemical mechanist. He saw chemistry as an independent science, a physical science.

In 1856, after presented a new thesis he was promoted to the position of privatdozent at the university, a position for which he had to present a dissertation. Its subject was silicon composites. At the beginning of 1857, he began to teach chemistry to help researchers in the university's laboratories. In 1859-1860 he worked at Heidelberg University, where he came into contact with Bunsen. In 1860 , he discovered the phenomenon of critical temperature-the temperature that gas or steam can become liquid only by increasing pressure, which he called absolute ebullition temperature. These studies then led him to consider once again the relationships of chemical properties and physical particles to their masses. In addition, he was convinced that chemical affinity forces were identical to cohesion forces; as a consequence, his research field can be considered as chemico-physics, a field where chemistry, physics and mathematics meet.

Mendeleev participated in the I International Chemical Congress, held in 1860 in Karlsruhe. Conceived by the famous chemist Kekulé, its main objective was to standardize the basic chemical concepts, such as atomic and molecular weights because the use of a variety of atomic weights by chemists created many difficulties for the development of chemistry. During the Congress, Mendeleev met many important chemists, such as Dumas, Wurtz, Zinin, and Canizzaro. The latter also agreed with Gerhardt's ideas as Mendeleev also did.

In 1865, he presented his $\mathrm{PhD}$ thesis: $O$ soedinenii spirta $s$ vodoyu (On the composites of alcohol and water) and for the first time he developed the idea that solutions are chemical composites so that the dilution of one substance in another would be consider as identical to other forms of chemical combination. 
In this thesis he also accepted the principles of chemical atomism.

The origins of Mendeleev's classification of chemical elements are attributed to 1867 , the year that he became chair of chemistry at St. Petersburg University (see Figure 10). He concluded that there was no acceptable text-book for students to follow in class. He then, began to write his own text-book in which the elements were organized in groups according to their valences with respect to hydrogen. The typical elements were Hydrogen (1), oxygen (2), nitrogen (3) and carbon (4). The book was entitled: Osnovy khimii (Chemical principles). The first part, which ended with halogens, was completed at the end of 1868. In January and February 1869, he wrote the first two chapters of the second part-on alkaline metals and specific heat. He organized the halogens and alkaline metals so that contrary chemical relationships were emphasized, although both presented the same valence. What was missing was organizing them according to another quantitative variable: atomic weight. The example follows.

It is easy to realize that his initial work-studies of the chemical properties of substances, specific weights and their relations with atomic and molecular weights, studies of atomic weights and their correlations with elements-had prepared him to the most important work of his life: the great synthesis of periodic law.

On May 1, 1869, Mendeleev obtained the response about which group of

ОПЫТЬ СИСТЕМЫ ЭЛЕМЕНТОВЪ, ОСНОВАННОЙ НА ИХЪ АТОМНОМЪ ВЬСЬ И ХИМИЧЕСКОМЪ СХОДСТВЪ.

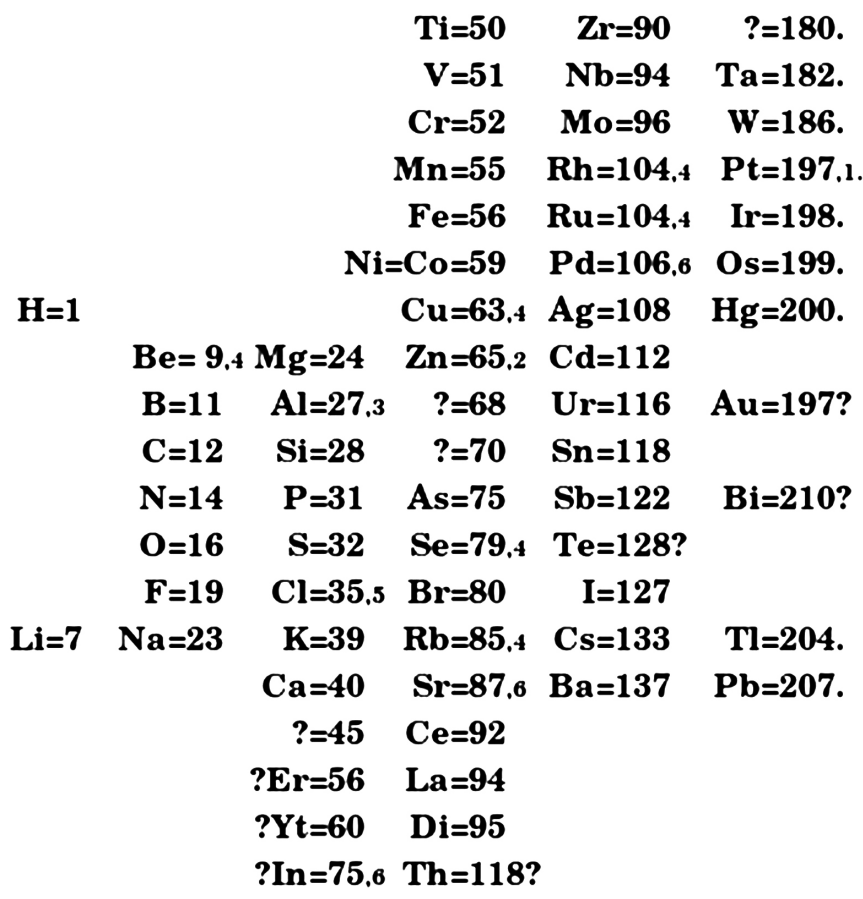

д. Мендельевъ

Figure 10. Mendeleev's original version of the periodic table. 
elements would be put into his table after the alkaline metals. The principle of atomicity led him to conclude that $\mathrm{Cu}$ and $\mathrm{Ag}$ must be treated as a transition group because they came from substances like $\mathrm{CuCl}$ and $\mathrm{AgCl}$, respectively, and thus it seemed logical to put them near alkaline metals due to their similitude in terms of chemical properties. Mendeleev was searching for a quantitative basis to justify this transition, when he had the idea of arranging the various groups of elements by order of atomic weight in a sequence that gave him an arrangement in the form of a table.

Mendeleev's work Osnovy Khimii led him to periodic law, formulated in March 1869. According to him "When arranged according to the value of atomic weights, the elements present a clear periodicity of properties." The first written report presenting his new discovery was read to the Russian Society of Chemistry in March 1869 by N. A. Menshutkin, as Mendeleev himself was absent.

Periodic law depended on a quantitative relationship between atomic weight, as an independent variable, and physical and chemical properties. In 1870, he studied the problem of how to develop a complete Natural system of elements. He applied deductions in order to achieve some important logic consequences, so that by checking these consequences he could confirm the law. The subsequent discovering of three elements predicted by Mendeleev was crucial to the acceptance of periodic law.

Ivan Petrovich Pavlov (1849-1936)

Pavlov (Dictionary, 2007) was born in Ryazan, on September 27, 1849 and died in Leningrad, today St. Petersburg, on February 27, 1936 (Figure 11). He was the son of a priest, Pyotr Dmitrievich Pavlov, and his mother was Varvara Ivanova. At eleven years of age he was sent to a religious school in Ryazan. After the conclusion of this course he went to the city seminary where began to study natural sciences. At this time, he discovered Refleksy golovnogo mozga (Brain reflexes) written by I. M. Sechenov and the popular works of D. I. Pisarev. He did not conclude his studies in the seminary. The example follows.

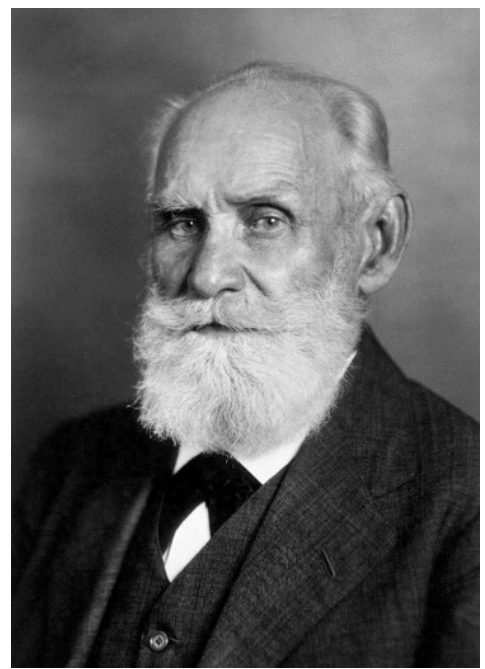

Figure 11. Ivan Petrovich Pavlov (1849-1936). 
In 1870 Pavlov entered the Department of Natural Sciences of the Physics and Mathematics Faculty in St. Petersburg. This course encouraged him to study physiology. At this time, he was awarded a gold medal due to his academic work written with M. I. Afanasiev (1875).

To improve his knowledge of physiology, he commenced a three-year course in the Academy of Military Medicine after graduating from the university (1875). This new course was concerned with theoretical medicine. In the Physiology laboratory in the Academy, Pavlov performed research on the physiology of blood circulation which put him in contact with S. P. Botkin. Later he organized and ran the Physiology Laboratories in Botkin's clinic (1879-1890), which gave to him the opportunity to investigate digestion as well as the physiology of blood circulation. On December 19, 1879, he received the degree of $\mathrm{PhD}$ in medicine. In 1881, he married Serafina Vasilievna Karchevskaya.

In 1883, Pavlov became Privatdozent in physiology in the Academy of Military Medicine and in 1890 was nominated professor of the Pharmacology Department. At the same time, he became director of physiology in the Experimental Medicine Institute and thus carried out interesting research on the physiology of digestion, publishing a paper in 1897.

In 1895, after the retirement of I. R. Tarkhanov, Pavlov moved to the physiology department, of which he was head until 1925. He concentrated his academic career for the rest of his life in three institutions: the Institute of Physiology of the Soviet Academy of Science, now the Institute of Experimental Medicine, and the biological station in Koltushy, today Pavlovo, near Leningrad, today St. Petersburg, and obviously the physiology department cited above.

Pavlov's scientific work was recognized internationally. In 1904 he received the Nobel Prize in physiology and medicine due to his research into digestion. In 1907, he was elected to Russian Academy of Science. In August 1935 he was invited to be the president of the XV International Congress of Physiology, held in Leningrad and Moscow.

Pavlov's contribution to physiology and natural sciences was of fundamental importance. He introduced a new methodology in physiology science. To him the living organism was a complex system whose functioning it was necessary to understand properly, using both analytical and synthetic methods in scientific research. However, the main problem in experimental research was to study reciprocal environmental influences on the organism.

Pavlov's investigations can be classified into three main areas: physiology of blood circulation (1874-1888), physiology of digestion (1879-1897), and brain physiology and superior nerve activity (1902-1936). His first researches on the physiology of circulation were concentrated on the mechanisms that regulate blood pressure. In his $\mathrm{PhD}$ thesis, he showed that heart function is regulated by four nerves, which respectively inhibit, accelerate, weaken, and intensify. Pavlov's research in this last area resulted in a publication in 1888.

Elsewhere Pavlov's research on the physiology of digestion $(1897-1906,1911)$ 
led him to prepare new techniques that changed his usual methods of work.

After his work on the physiology of digestion, Pavlov turned his attention to behavioral physiology. At the beginning of the twentieth century many physiologists, zoologists, and psychologists performed experiments to study brain function, but the information was neither sufficient nor complete. Pavlov then drew on Darwin's theory of evolution, which emphasized psychological and physiologic continuity, and Sahenov's reflexology to create his own behavioral theory. He described as follows the genesis of his behaviorism: Our time is adequate to perform an experimental analysis of the being, from an objective and external point of view, as happens in other natural sciences. This transition allows for the new comparative physiology that arisen under the influence of evolutionary theory.

Pavlov had publicly communicated his theory of conditioned reflexes in 1903, at the XIV International Medicine Congress, held in Madrid. He found in conditioned reflexes a mechanism of individual adaptation which existed in the animal world. According to him: A nervous temporary connection is a universal physiological phenomenon in the animal world and it really exists in ourselves. He identified in brain hemispheres the locus of these activities which produces the conditioned reflexes, by also proved that the center of this activity would be found in the cortex.

Finally, Pavlov created a great school based on research, which at certain periods employed around 300 physiologists and medical doctors. In addition, he organized several research centers, including the Department of Physiology at the Institute of Experimental Medicine, the Physiological Institute of the Soviet Academy of Science, as well as the biological station in Koltushy. With Pavlov's help the Russian Physiological Society, now the I. P. Pavlov Physiological Society, was set up in 1917.

\section{Final Remarks and Conclusion}

Before the 1917 Revolution, Russian science, as a whole, lagged behind the leading countries of the West, but was in a process of development. However, in some areas and in some aspects, this process was accelerated or even at the same level as the more developed countries. We can underline areas such as mathematics, physiology, astronomy, and some branches of physics, biology and chemistry where remarkable Russian scientists had demonstrated their international capacity. Names are Mendeleev, Lobachevski, Chebyshev, Kovalevskii, Pavlov, and many others progressively occupied places of prestige in the history of sciences.

Scientific societies such as the Russian Physical-Chemical Society (1869) are comparable with similar societies from outside Russia. At the time of the Russian Empire, there existed ten universities in the country. The oldest was Moscow University, founded in 1755. On the other hand, the Imperial Academy of Science produced high level research throughout the nineteenth century and 
during the early years of the twentieth. This context and these institutions gave the Russian Revolution the necessary support for further developments in science and technology.

In the first phase of Russian Revolution, in February 1917, under the provisional government, when liberals and democratic socialists were in power, many reforms were implemented and had a positive influence on the future of Soviet science (Montefiore, 2005). Universities and professional societies affirmed their independence in related state control. In the second phase in late 1917, groups of intellectuals and specialists expressed their disagreement with the new regime, declaring strikes, promoting informal boycotts, and frequently ignoring Soviet orders. But this initiated another chapter of the Russian Revolution outside the scope of this paper.

\section{Conflicts of Interest}

The authors declare no conflicts of interest regarding the publication of this paper.

\section{References}

Anderson, M. S. (1978). Peter the Great. New York: Routledge.

Bernoulli, D. (1738). Hydrodynamics. New York: Dover Publications, Inc.

Brooke, C. (2006). Moscow a Cultural History. New York: Oxford University Press.

Carr, E. H. (1979). The Russian Revolution from Lenin to Stalin 1917-1929. London, England: The MacMillan Press Ltd.

Chakravanti, R. N. et al. (1987). Soviet Union: Land and People. Northern Book Centre.

Dictionary of Scientific Biographies. (2007). Brazilian Edition (Contraponto) (Vol. 1, pp. 751-768). Brazil: Contraponto.

Dictionary of Scientific Biographies. (2007). Brazilian Edition (Contraponto) (Vol. 2, pp. 1725-1732). Brazil.

Dictionary of Scientific Biographies. (2007). Brazilian Edition (Contraponto) (Vol. 1, pp. 459-469). Brazil.

Dictionary of Scientific Biographies. (2007). Brazilian Edition (Contraponto) (Vol. 3, pp. 1901-1910). Brazil.

Dictionary of Scientific Biographies. (2007). Brazilian Edition (Contraponto) (Vol. 3, pp. 2194-2198). Brazil.

Graham, L. R. (1993). Science in Russia and the Soviet Union. Cambridge: Cambridge University Press.

Graham, L., \& Dezhine, I. (2008). Science in the New Russia: Crisis, Aid, Reform. USA: Indiana university Press.

James, I. (2002). Remarkable Mathematicians: From Euler to von Neumann. Oxford, England: Cambridge University Press.

Karp, A., \& Vogeli, B. R. (2010). Russian Mathematical Education. History and World Significance, Series on Mathematical Education (Vol. 4). Covent Garden: World Scientific Publishing Co., Pte., Ltd. https://doi.org/10.1142/9789814277068_0009

Kirchner, W. (1982). Siemens and AEG and the Electrification of Russia, 1890-1914, 
Seiner.

Koblitz, A. H. (2013). Science, Women and Revolution in Russia. London and New York, NY: Routledge Taylor \& Francis Group.

Lieven, D. (2006). The Cambridge History of Russia, Vol. II: Imperial Russia, 1689-1917. Cambridge: Cambridge University Press.

Montefiore, S. S. (2005). The Court of the Red Tsar. St. Paul: Schwarcz Editors.

Oliveira, A. R. E. (2007). Euler's Contribution to Classical Mechanics. In 12th IFToMM World Congress. Besançon, France.

Owen, T. C. (1995). Russian Corporate Capitalism: From Peter the Great to Perestroika. New York, NY: Oxford University Press.

Pavlova, G. E. et al. (1984). Mikhail Vasil'evich Lomonosov: His Life and Work. Moscow: MIR Publishers. 